\title{
THE FATWA OF THE COUNCIL OF INDONESIAN ULAMA ON INTER-RELIGIOUS MARRIAGE
}

\author{
R. Cecep Lukman Yasin \\ Pasca Sarjana UIN Maliki Malang \\ Telepon: 081334102625 \\ Email:lukmanyasin@yahoo.com
}

\begin{abstract}
The Qur'anic text states that it is lawful to marry women from among the People of the Book, while in the prophetic tradition it is reported that the Prophet himself had a nonMuslim wife. However, the campaign to propagate Christianization which had been tirelessly carried out by well-organized missionary organizations was reported to have successfully christianized segments of the Indonesian population especially in the heathen hinterland and among outer island tribes. Given the circumstances, the Muslim leaders and ulama perceived inter-religious marriage as a hidden Christianization. The increasing incidence of inter-religious marriage raised the concern of the Indonesian Council of Ulama. Responding to this problem, in June 1, 1980 the Council issued a fatwa which explicitly prohibits a Muslim to marry a non-Muslim. Even though the position adopted by the fatwa was quite a radical departure from the prevalent opinion in classical fiqh text, this legal opinion is still within the permissible frame of Islamic legal theory of maslahah (beneficial theory). This legal theory is encapsulated in the Syafi'i school's legal maxim stating that "Dar'u al-mafâsid muqaddam 'alâ jalb al-masâlih" (Preference is given to the prevention of harm than to attainment of benefit)
\end{abstract}

Al-Quran menegaskan kehalalan menikahi wanita Ahl al-Kitab, sementara hadis menyebutkan bahwa Nabi sendiri beristeri seorang non-Muslim. Namun, gerakan kristenisasi yang dijalankan oleh lembaga missionaris terorganisir telah berhasil memurtadkan sejumlah penduduk Muslim Indonesia, terutama di daerah pinggiran dan pedalaman. Karena itu, para ulama dan pemimpin Islam memandang pernikahan beda agama sebagai bagian dari gerakan kristenisasi terselubung. Tingginya kasus pernikahan beda agama memunculkan keprihatinan Majlis Ulama Indonesia (MUI). Menanggapi masalah ini, pada 1 Juni 1980, MUI mengeluarkan fatwa yang secara tegas melarang seorang pria Muslim menikahi wanita non-Muslim. Meskipun menyimpang dari pendapat yang dianut dalam figh klasik, fatwa ini masih berada dalam bingkai teori hukum Islam yang dikenal dengan konsep maslahah. Teori hukum ini dirumuskan dalam kaidah fighiyah madzhab Syafi'i yang berbunyi "upaya mencegah kemudaratan lebih didahulukan dari pada upaya meraih kemaslahatan."

Keywords: Fatwa, The Council of Indonesian Ulama, Inter-Religious Marriage

\section{Introduction}

In spite of differences in doctrine between Islam and the People of the Book, Islam recognizes that in principle Jews and Chris- tians are believers in a revealed religion and followers of the prophets, Moses and Jesus respectively. Both relate to the religion of Abraham, the common grandfather of the 
Prophets. Unless they are actively fighting against Islam, the relation between Muslims and the People of the Book is one of the compassion and cooperation. They eat each other's food and enter each other's houses as friendly guests. They should never be forced or pressured to convert to Islam against their conviction. ${ }^{1}$

The most convincing example of the tolerant and friendly attitude of Islam towards the People of the Book is that Islam makes it permissible for a Muslim man to build the sacred unit of humanity, i.e. the family, by marrying a Christian or a Jewess woman. Islam gives her the right to keep to her faith, and makes it a religious duty on the husband to enable her to observe her rites and worship according to her religion. Obviously, Islam builds the bridges rather than the rifts. The reason of the permissibility of Muslim man to marry a woman of the People of the Book is that both parties have similar basic beliefs, such as beliefs in God, the Messengers, and the Hereafter. The existence of these similarities will guarantee the realization of harmonious marital life, and her coming to Islam could be hoped for. However, a Muslim woman is prohibited to marry a non-Muslim man. The reason of the permission for Muslim man to marry a woman of the People of the Book, but not vise versa, is that he believes in all the Messengers of God, so there is no fear that he will hamper her faith and ritual practices. As for a non-Muslim man, he does not accept Islam as true religion, so there exists an obvious danger of putting his wife under the influence of his religion, and therefore her marriage will bring harm to her faith and ritual practices. ${ }^{2}$

In short, Islam has made marriage to Christian or Jewess women lawful for Muslim men, for they are the People of the Book, whose tradition is based upon a divinely revealed Scripture. However on 1 June 1980 the Council of Indonesia Ulama (Majelis

\footnotetext{
1 QS. 2: 256.

2 Wahbah al-Zuhaylî, Al-Fiqh al-Islâm wa
} Adillatuh, Vol 7 (Beirut: Dâr al-Fikr, 1989), p. 153.
Ulama Indonesia, MUI) ${ }^{3}$ issued a fatwa declaring the prohibition of inter-religious marriage. This fatwa is a repercussion of rivalry between Muslims and Christians in Indonesia, dating from as early as the beginning of the twentieth century. Under the Dutch, Muslims rallied to compete with Dutch-sponsored Christian missionaries. Extensive financial support was provided by the Dutch to the Christians, far exceeding that given to the Muslims. Suminto shows, for example, that in 1917 the Christians were provided with 1,235,500 guilders compared to only 127,029 provided for the Muslims. ${ }^{4}$ Noer also showed that the same disparity existed in 1930s. ${ }^{5}$ Rumor has it that the Christians planned to convert Java in 20 years and all of Indonesia in 50 years. After the abortive Communist coup of 1965 and the banning of communism in 1966, it was claimed that 2 million Indonesians had converted to Christianity.

The fatwa under study becomes the cornerstone of the ensuing debate of the banning of inter-religious marriage in Indonesia, and over the last three decades, marriage between couples of different religion has generally sparked controversies, as the state does not recognize inter-religious marriage. The issue of inter-religious marriage is also reflected in the court decision; in 1986 the Central Jakarta District Court decided that marriage between Muslim and non-Muslim could not take place, and in 1989 Supreme Court prohibited partners of different religion to marry without one party abandoning his or her religion. ${ }^{6}$ Article 40 of the 1991 Compilation of Islamic Law also prohibits a Muslim man of marrying a woman who does not profess the Islamic religion. Earlier, Article 2

3 For the rest of the paper, this acronym will be used to refer to the Council of Indonesian Ulama.

4 See H. Aqib Suminto, Politik Islam Hindia Belanda (Jakarta: LP3S, 1985), p. 32-34.

5 Deliar Noer, The Modernist Muslim Movement 1900-1942 (Singapore: Oxford University Press, 1973), p. 170.

6 Sebastian Pompe, "A Short Note of Some Recent Development with Regard to Mixed Marriages in Indonesia," Bijdragen tot de Taal-, Land- en Volkenkunde, Vol 2e \& 3e (Leiden: KITLV Press, 1991), p. 262. 
(1) of Marriage Law of 1974 incorporates religion into the state law by specifying that marriages must be concluded in accordance with the rules of the religion of both parties. In other words, there is no marriage outside of the laws of the religions. In addition to the fatwa under study, all these regulations would make inter-religious marriage impossible to conclude. Consequently, there is a legal vacuum in the area of inter-religious marriage.

This present paper examines the debates on inter-religious marriage in Indonesia with special emphasis on the fatwa of MUI. To put the fatwa in a wider context, the relevant court rulings and laws relating to this issue will be discussed, because the writer argues that the fatwa cannot be separated from the century-aged debate about the interreligious marriage in Indonesia. To broaden our discussion, the paper tries to shed the light on the development of this issue in Indonesian legal history and controversies surrounding it. As a main issue in this paper, the fatwa will be dealt first and followed by the discussion of the relevant court rulings and laws on inter-religious marriage.

\section{Translation of the Fatwa}

In the name of Allah Most Gracious, Most Merciful

The Council of Indonesian Ulama in the Second National Assembly on 11-17 Rajab 1400/26 May-1 June 1980, after taking into consideration:

1. God's utterance:

"Do not marry unbelieving women until they believe. A slave woman who believes is better than an unbelieving woman, even though she allure you. Nor marry (your girls) to unbelievers until they believe. A man slave who believes is better than an unbeliever even though he allure you. Unbelievers do (but) beckon you to the Fire. But Allah beckons by His Grace to the Garden (of bliss) and forgiveness, and makes His Signs clear to mankind. That they may receive admonition." (Q.S. Al-Baqarah: 221).
2. God's utterance:

"(Lawful unto you in marriage) are (not only) chaste women who are believers, but chaste women among the People of the Book, revealed before your time - when ye give them their due dowers, and desire chastity, not lewdness, nor secret intrigues. If anyone rejects faith, fruitless is his work, and in the Hereafter he will be in the ranks of those who have lost." (Q.S. Al-Maidah: 5).

3. God's utterance:

"... If ye ascertain that they are believers, then send them not back to the unbelievers. They are not lawful (wives) for the unbelievers, nor are the (unbelievers) lawful (husband) for them." (Q.S. Al-Mumtahanah: $10)$.

4. God's utterance:

"O ye who believe! Save yourselves and your families from a Fire ..." (Q.S. Al-Tahrim: 6).

5. The Prophet Muhammad's saying:

"Whoever has married, he has preserved a half of his faith. Therefore, he is supposed to fear God in the other half." (Narrated by Tabrânî).

6. The Prophet Muhammad's saying:

"Every human being is born in fitrah. It is only the parents who make them Jews, Christians or Zoroastrians." (Narrated by Aswad ibn Sura'i)

Decides to issue a fatwa that:

1. The marriage between a Muslim woman and a non-Muslim man is unlawful (haram)

2. A Muslim man is unlawful to marry a nonMuslim woman. There are different opinions concerning the status of marriage between a Muslim man and a woman of the People of the Book. After considering that the harm (mafsadah) of such a marriage is bigger than the benefit (maslahah) of it, the Council of Indonesian Ulama issues a fatwa that such a marriage is unlawful (haram).

Jakarta, 17 Rajab 1400/1 June 1980

The Head of National Assembly

The Council of Indonesian Ulama

$\begin{array}{ll}\text { Chairman } & \text { Secretary } \\ \text { Signed } & \text { Signed } \\ \text { Prof. Dr. Hamka } & \text { Drs. H. Kafrawi }\end{array}$




\section{Analysis of the Fatwa}

The fatwa was issued on June 1, 1980 as a response to the growing concern in society about the increasing incidence of inter-religious marriages. The fatwa made two direct statements about the issue. Firstly, that a Muslim woman is forbidden (haram) to marry a non-Muslim man; and secondly, that a Muslim man is prohibited to marry nonMuslim woman. The fatwa was signed by Hamka dan Kafrawi, the general and the secretary of the MUI respectively.

The arguments put forward by the fatwa consist exclusively of Qur'anic and hadith quotations, and no reference is made to any fiqh text. The first Qur'anic verse quoted concerns the prohibition of marriage between Muslim man and a mushrik (idolator), because Allah considers a Muslim slave better than an idolator; ${ }^{7}$ the second concerns the permissibility of marriage between a Muslim man and a woman of ahl al-kitâb (the people of the book, namely Christians and Jews) $;{ }^{8}$ the third concerns the prohibition of marriage between a Muslim woman and an unbeliever (kâfir); the fourth concerns the command to keep oneself and one's family from going to hell. ${ }^{9}$ The hadiths quoted are concerned, firstly with the doctrine that a good marriage is equal to half of the faith, and secondly, with the belief that children are born pure (fitrah); only the parents make them Jews, Christians, or Zoroastrians.

The interesting thing about the fatwa is that, while the Qur'an explicitly permits a Muslim man to marry a woman of the ahl al$k i t a ̂ b$, the fatwa does not. It forbids such a marriage on the grounds that the mafsada (harm) is greater than the maslaha (benefit). Although the fatwa refers specifically to the case of Indonesia, it is a radical position, for it contradicts the explicit statement of the Qur'an. It also contradicts classical fiqh texts that had so far been consulted by the MUI for other fatwas. Classical fiqh texts are in

\footnotetext{
7 QS. 2: 221.

8 QS. 5: 5.

9 QS. 66: 6.
}

agreement concerning the permissibility of marriage between a Muslim man and a woman of the ahl al-kitâb. The question arises as to what the basis for the MUI's contradiction of the Qur'an was.

Sociologically speaking, it seems relevant to note that the issuance of the fatwa was triggered by the religious rivalry between Muslims and Christians. Indonesia in 1980s had witnessed a new trend of what is called a Pancasila marriage, in which the marriage between a Muslim woman and a non-Muslim man was conducted under the procedures of the man's religion. ${ }^{10}$ This phenomenon added fuel to the Muslim's suspicion about the systematic Christian mission through interreligious marriage. The term and practice of Pancasila marriage were considered a violation against the Muslim belief since the marriage for Muslims is not only a matter of external agreement involving the reproducetion of human beings, but a sacred bond aimed at achieving both happiness and obedience to God. Hence, adherence to the same religion by the marrying parties is a prerequisite. Moreover, the sphere of personal law is considered as the heart and core section of the Shari'ah since the injunctions in marital law were comparatively fully dealt in the Qur'an. This fact also explains that, while all other key areas of modern legallegislative life, especially in criminal, constitutional, and commercial law have welcomed Western legal influence, the sphere of Islamic personal law is relatively immune from Western legal penetration. ${ }^{11}$ Therefore, any attempt to change the practice of Islamic family law will face great resistance from the Muslims.

The fatwa under discussion uses only the term "non-Muslim" with no further qualification. However, it is obvious that it refers to the Christians, for all cases of inter-reli-

10 Mohammad Atho Mudzhar, Fatwa-Fatwa Majelis Ulama Indonesia Studi tentang Pemikiran Hukum Islam di Indonesia, 1975-1988 (Jakarta: INIS, 1993), p. 101.

11 Abraham Udovitch, Partnership and Profit in Medieval Islam (Princeton: Princeton University Press, 1970), p. 7. 
gious marriages referred to by the MUI involve Muslims and Christians. Moreover, any mention of the ahl al-kitâb made by Indonesian Muslim necessarily refers to Christians, for Jews are not found in Indonesia. Thus, the real issue addressed by the fatwa on inter-religious marriages is to prevent Muslim men and women from converting to Christianity. This interpretation is particularly relevant in view of the continuing rivalry between Muslims and Christians in the country, and of the preoccupation of the Muslims with the threat of Christianization.

The issuance of the fatwa prohibiting Muslim men and woman from marrying nonMuslims even of the ahl al-kitâb seems to have been triggered by that religious rivalry despite the explicit statement of the Qur'an on the permission granted to Muslim men to marry woman of the ahl al-kitâb. This might mean that the rivalry was already considered by the 'ulama to have reached such a point that, for the sake of the Muslim community's growth, the doorway to inter-religious marriage had better be shut altogether. The question may arise here as to why the "ulama are concerned with the size of the Muslim community when Muslims in the country constitute an overwhelming majority. The answer seems to be that Indonesian Muslim constitutes quantitative majority, and at the same time qualitative minority.

Methodologically speaking, the fat-wa entails the replacement of a Qur'anic verse by the masâlih al-mursalah (the interest of the Muslim community), or at least the postponement of the application of particular injunctions in the Qur'an due to special circumstantial necessity. This principle of masâlih al-mursalah was widely applied by the second caliph 'Umar ibn al-Khaththâb, and later advocated by Mâlik ibn Anas as one of the sources of Islamic law. 'Umar is reported to have made several decisions that can be considered contradictory to the explicit statement of certain Qur'anic verses, as he thought that in certain circumstances the masâlih mursalah should be given priority above all else. Accordingly, he ruled against the cutting off of the hands of thieves in time of famine. He refused to give a portion of zakât (alms tax) to the mu'allafa quîbuhum (non-Muslims whose sympathy is needed), once the Islamic community had grown strong enough to meet outside challenges. He also refused to divide conquered lands in Iraq among the fighting soldiers and left them instead to the cultivators and collected the taxes from them for the states. ${ }^{12}$ All of these decisions appear on the surface as to contradict certain Qur'anic verses, but 'Umar thought that they were more in line with the spirit and the essence of Islamic teaching, the maslahah. ${ }^{13}$ This is to say that the issuance of the MUI's fatwa on inter-religious marriage which is, on the surface, contradictory to an explicit statement of the Qur'an, has its precedence in the practice of the second caliph. For the sake of maslahah al-umma, the MUI prohibits a Muslim man from marrying a woman of the ahl al-kitâb although it is permitted in the Qur'an.

Apparently the MUI was not the first to do so in modern times, for Mahmud Shaltut in the 1960s said the same with one qualification. He said that if the Muslim man was weak and would follow the traditions of this prospective wife, his marriage with her should be forbidden. Shaltut argued that here one applied the same reason as when the Qur'an prohibited a Muslim woman from marrying a non-Muslim man, even if the man was of the ahl al-kitâb. He claimed that the reason was to prevent Muslims from converting to the religion of the ahl al-kitâb. ${ }^{14}$ The concept of maslahah is also used by Yusuf Qaradawi when he states that if a number of Muslim in a country is small, for instance if they are immigrants residing in a non-Muslim country, their men ought to be prohibited from marrying non-Muslim wo-

12 The vast discussion on the manhaj (method or procedure) of 'Umar in enacting the law is provided by Muhammad Biltaji, Manhaj 'Umar ibn alKhaththâb fi al-Tasyrî' (Cairo: Dâr al-Salâm, 2002).

13 Literally, maslahah (pl. masâlih) means "benefit" or "interest." It is synonymous with istislâh.

14 Mahmûd Shalthûth, al-Fatâwâ (Cairo: Dâr al-Qalam, n.d.), p. 279-280. 
men because, since Muslim women are prohibited from marrying non-Muslim men, their marriage to non-Muslim women means that many Muslim girls will remain unmarried. Since this situation is injurious to the Muslim society, this injury can be avoided by temporarily suspending this permis sion. ${ }^{15}$

From the discussion above, it is clear that maslahah turn to be the backbone of modern legislation. However, Muslim legists are in disagreement upon the concept of maslahah as a source of legal injunction. The main point in the argument advanced by the opponents of istihlâh is that the Shari'ah takes full cognizance of all the maslahah (public interest). This is the view of the Zahirites and some Shâfi'ites. According to these groups of Muslim legists, there is no maslahah outside the Shari'ah. When the Shari'ah is totally silent on a matter, it is an obvious sign that the maslahah in question is no more than a specious maslahah (maslahah wahmiyah) which is not a valid ground for legislation. The Hanafites and most Shâfi 'ites adopted a relatively more flexible stance, maintaining that maslahah is either validated in the explicit texts (nusus), or indicated in the rationale (illah) of a given text (nashsh), or even in the general objectives of the Lawgiver (maqâsid al-Shâri) ${ }^{16}$ The main difference between these two opposing views is that the later validates maslahah on the basis of the rationale and the objective of the Shari'ah (maqâsid al-Shari'ah) even in the absence of a specific text. However, both views are founded in the argument that if maslahah is not guided by the values upheld in the texts, there is a danger of confusing maslahah with arbitrary desires, which might lead to corruption and harm. The maslalah

15 Yusuf al-Qaradawi, The Lawful and the Prohibited in Islam, translated by Ahmad Zaki Hammad (Indianapolis: A merican Trust Publications, n.d.), p. 184; see also Wahbah al-Zuhaylî, p. 155.

16 The issue whether or not the intention of the Lawgiver can be known by human reason also constitutes theological and legal debates within Muslim legists. For further treatment on this issue, see al-Shâthibî, al-Muwâfaqât Vol. 2 (Cairo: Dâr Ibn 'Affần, 2000), p. 9-13. must therefore be guided by the values that the Lawgiver has upheld.

Judging from this concept of maslahah, it seems that the fatwa under discussion not only lacks the explicit text, but also contradicts to the text. However, if we go deeply into the context and the spirit of the fatwa, we will find the basic reason of the fatwa. MUI's fatwa on the prohibition of inter-religious marriage is parallel to the objective of the Shari'ah (maqâsid al-Sharî'ah) in which protection of the faith constitutes its top hierarchy. According to the concept of maqâsid al-Shari'ah, the purposes of Shari'ah is to preserve the five essential values, namely religion, life, intelligence, progeny, and wealth. Any measure which secures these values falls within the scope of maslahah, and anything which violates them is deemed mafsadah (harm), and preventing it is considered maslahah. ${ }^{17}$ If the permission to marry women of ahl al-kitâb will lead to harm Muslim society at large, the measure to postpone or repeal the application of the Qur'anic injunction regarding the permissibility of marriage with women of ahl al-kitâb falls within the scope of maslahah.

What is also interesting about the fatwa under discussion is that it adopts the theory expounded by a prominent Hanbali jurist, Najm al-Dîn al-Tûfî̀ who authorizes recourse to maslahah with or without the existence of the text. In his commentary on the hadith ("no harm shall be inflicted or reciprocated"), al-Tûfî argues that this hadith provides a clear text in favor of maslahah. ${ }^{18}$ According to him, it enshrines the first and most important principle of Shari'ah and enables maslahah to take precedence over all other consideration. This principle applies only to the transaction and governmental affairs (ahkâm al-mu 'âmalah wa al-siyâsah al-dunyawiyah). In these areas, maslahah constitutes the goal whereas the other proofs are like the means; the end

17 Al-Ghazali, Al-Mustasyfâ min 'Ilm al-Usul Vol. 1 (Beirut: Muassasah al-Risâlah, 1997), p. 417.

18 Najm al-Dîn al-Tûfî, Risâlah fi Ri âyat alMaslahah (Cairo: Al-Dar al-Misriyah al-Lubnaniyah, 1993), p. 23. 
must take precedence over the means. ${ }^{19}$ The rules of Shari'ah in general and particular have been enacted in order to secure the masâlih of the people, and therefore when the text and other proofs of Shari'ah happen to oppose the maslahah of the people, the later should take precedence over the first.

\section{Inter-religious Marriage in Indonesian Le- gal System}

Inter-religious marriage constitutes one of the most controversial issues in Indonesia legal history. This fact is well illustrated by the debates in and outside of Parliament over the "comprehensively and specifically secular" Marriage Bill, introduced in 1973. Muslims strongly objected to several aspects of the Bill which were contrary to Islamic law. In particular, for our purpose, the Bill permitted inter-religious marriage. In the face of the intense Muslim opposition, the government enacted an amended statute which largely accommodated Muslim interest: Law No. 1 of 1974 on Marriage. In this law, article allowing inter-religious marriage was removed.

Marriage Law of 1974 incorporates religion into the state law, article 2 (1) of which specify that marriages must be conclude in accordance with the rules of the religion of both parties. At the same time, this law is generally held to contain no explicit legislateve provision for marriage between partners of different religions. Before 1974, the formal legal right of Indonesians to marry a partner who adhered to a different religion to their own was undisputed. According to Article 7 of the Regeling of de Gemengde Huwelijken of 1896 (Mixed Marriage Regulation, GHR), a decree which first applied to Indonesians under Dutch rule, a difference in religion between prospective marriage partners could not prevent them from marrying. ${ }^{20}$ Inter-religious marriages were to be concluded according to

\section{${ }^{19}$ Ibid., p. 45}

20 June S. Katz and Ronald S. Katz, "The New Indonesian Marriage Law: A Mirror of Indonesia's Politics, Cultural, and Legal Systems," The American Journal of Comparative Law, vol. 23 No. 4 (Autumn, 1975), p. 662. the law of the husband. The GHR did not required that the wife convert to her husband's religion for the purpose of marriage; only that she cede to her husband's legal regime. Muslims generally hold inter-religious marriage in contempt of Islamic law. For decades they objected to the provision in the GHR which permitted such marriages. Nevertheless, the courts almost inevitably upheld this colonial regulation.

Since the enactment of the Marriage Law of 1974, inter-religious marriage law has been in a constant state of flux. The Marriage Law and its implementing regulation do not explicitly provide either for or against marriages between Indonesians adhering to different religions. This generated a great deal of debate over whether partners of different religion could actually marry under Indonesian law. Some argue that the Marriage Law implicitly regulated inter-religious marriages. Article 2 (1), which provides that the religious prescripts of the parties are to be used to conduct marriages, is seen to extend to inter-religious marriages. Such marriages would be permitted only as far as these religious prescripts allowed. Those who advocate this approach generally conclude that most Indonesians could not lawfully marry inter-religiously unless one of them converted to the other's religion. The court, however, did not accept that Article 2 (1) extended to encompass interreligious marriage. The established view was that the Marriage Law did not explicitly provide for inter-religious marriage, and thus it had no effect on the existing colonial regulations which permitted it. Article 66 of the Marriage Law states that the Law repeals other laws and regulation containing provisions relating to marriages that conflict with it. The court argues that since inter-religious marriage is not regulated in the Marriage Law of 1974, the GHR should still apply. Apparently in contravention of Article 2 (1), the Supreme Court issued a Circular letter in 1975 instructing the lower courts to apply the colonial regulations in cases of inter-religious marriage. ${ }^{21}$ Thus in 1975 , one year after the

21 Sebastian Pompe, “A Short Note...”, p. 263. 
enactment of the Marriage Law, Indonesian courts ruled that inter-religious marriage could be concluded at the Civil Registry Office, which has the authority to perform marriages between non-Muslim, continuing in effect to make civil marriage possible despite Article 2 (1) of the Marriage Law. ${ }^{22}$ This opened the way to marriage between partners of different religions. However, in 1984 the Ministry of Religion issued a guide to marriage registry officials of Board of Religious Affair, who have authority to conclude Muslim marriages, stating that they could only register marriage between Muslims. By 1987 there were reports that it had become impossible to formalize inter-religious marriage at the Civil Registry Office. ${ }^{23}$ This was due to a decision made at a meeting between the Ministers of the Interior, Justice and Religious Affairs in January 1987 that civil mixed marriages could not proceed. Since 1987, there have been increasingly frequent press reports that members of differrent religions wishing to get married were being turned a way by both the Board of Religious Affairs and Civil Registry Office.

Earlier, the Central Jakarta District Court strengthened this trend in 1986 when it held that a marriage between a Muslim women and a non-Muslim man could not be formalized. ${ }^{24}$ Officials at the Board of Religious Affairs had refused to formalize the marriage because the prospective husband was a non-Muslim, so the marriage was in discord with Islamic law. The marriage could neither be concluded at the Civil Registry Office because the woman was a Muslim. The couple then started proceedings against both offices on a charge of wrongful action, demanding that their marriage be formalized

22 June S. Katz and Ronald S. Katz, "Legislating Social Change in a Developing Country: The New Indonesian Marriage Law Revisited," The American Journal of Comparative Law, Vol. 26 No. 2 (Spring, 1978), p. 315.

23 Sebastian Pompe, "Mixed Marriage in Indonesia: Some Comments on the Law and the Literature," Bijdragen tot de Taal-, Land-en Volkenkunde (Leiden: KITLV Press, 1988), Vol 144, p. 262.

24 Sebastian Pompe, "A Short Note...", p. 262263. by the Civil Registry Office. The court dismissed their claims, upholding that both the Board of Religious Affairs and the Civil Registry Office had been right in refusing to marry them. The court held a view that the former was right because the marriage was contrary to Islamic religious prescription incorporated in the Article 2 (1) of 1974 Marriage Law, and the latter because it was not authorized to marry a Muslim party. This court ruling made marriage between partners of different religions impossible to conclude.

Then the couple brought the issue to the Supreme Court. The first question to be settled was about the jurisdiction conflict between religious court and civil court on the refusal of formalizing marriage on the ground of a difference in religion. ${ }^{25}$ As it had in previous rulings, the court also decided that the Marriage Law did not provide for marriage between partners of different religions. ${ }^{26}$ However, instead of going on to hold that the GHR applied to this type of marriage by the virtue of Article 66 of the Marriage Law, which states that previous legislations are voided insofar as the subject concerned is provided in this law, the court went against prior Supreme Court Jurisprudence and deci-

25 The Court decided that the refusal to formalize such a marriage come under the jurisdiction of a civil court. The ruling reads: Considering that, although the petitioner is a Muslim and the regulations of article 63, subsection 1a, of Law No. 1 of 1974 make it clear that, if the intervention of a court is required, then the case would come under the jurisdiction of a religious court, it is nevertheless also obvious that, because the refusal to perform the marriage was base on a difference of religion, the said refusal constitutes no interdiction on a formalization of the marriage under the provision of article 8 of the said Law No. 1 of 1974, and because the present case does not constitute a case as meant by article 60 , subsection 3, of Law No. 1, 1974, this case rightly comes under the jurisdiction of a civil rather than a religious court.

26 The ruling reads: Law No. 1 of 1974, concerning marriage, contains not a single regulation which says that a difference in religion between the prospective husband and wife constitutes an obstacle to marriage. This is in accordance with article 27 of the Constitution of 1945, which specifies that all citizens are equal before the law, which includes equality of the basic right to marry a fellow-citizen, regardless of any difference of religion. 
ded that the GHR was based on a civil marriage system which has since been abandonned in Indonesia. Marriage is now a religious affair, not merely civil relationship. ${ }^{27}$ Consequently, there is no law governing inter-religious marriage. This court ruling in fact creates a legal vacuum. The question then remaining is what law should apply in such a vacuum. Determined to prevent Registry Officials from balking mixed marriages, the Court found a legal basis to allow them. Furthermore, the court argued that because the couple applied to the Civil Registry Office after being refused by the Board of Religious Office it must have been their intention to have their marriage formalized not in accordance with Muslim religious prescriptions. In particular, the woman must not have wished to marry in accordance with Islamic law, and in fact abandoned it. The Supreme Court held that the couple could therefore conclude their marriage at the Civil Registry Office and ordered the institution to formalize the marriage. ${ }^{28}$

27 The ruling reads: However, the provision of the Mixed Marriage Regulation (S. 1898, no. 158) and the Marriage Ordinance for Christian Indonesian (S. 1933, no. 74) are not applicable, because there is a wide difference in principle as well as philosophy between the Marriage Law of 1974 and the two aforementioned ordinances. This difference is that the Marriage Law embraces the principle that a marriage is legal when it is performed in accordance with the laws of the religion and faith of the respective parties, this being the outcome of the Pancasila as the state philosophy. Marriage here is viewed no longer as an exclusively civil affairs, as marriage possesses extremely close link with religion/creed, so much so that marriage outside the laws of the religion and faith of the two parties is impossible. Whereas the marriage provisions of the Civil Code as well as the Marriage Ordinance for Christian Indonesian and the Mixed Marriage Regulation all view the question of marriage as a strictly civil affairs. (Italics in original.)

28 The ruling reads: Considering that, in submitting an application for the formalization of a marriage to the Chief Civil Registrar in Jakarta, this should be interpreted as testifying to an intention of having the marriage formalized not in accordance with Muslim religious prescriptions, this in turn should be interpreted as testifying that, in submitting the application, the applicant no longer had any regard for the status of her religion (in this case the Muslim religion), so that article 8, clause f, of the Law No. 1 of
The Supreme Court's decision discussed above represents an attempt by the court to reverse the trend in which certain state organs obstruct inter-religious marriages. Implicitly, this ruling indicates that the Civil Registry Office is the appropriate agency to perform marriage in which the partners adhere to different religious creeds. A closer look of this ruling reveals that the court precisely adopts the colonial Mixed Marriage Regulation that prescribes that the woman shall adopt the legal status of the man. This is a backward step for Indonesian women who have struggled for the legal equality. On what ground the women should cede to the man's religion or legal system, and not vise versa, is left unanswered.

Finally, it could be said that compared to matters belonging to the public domain, some religious matters are too delicate to be treated by the state authorities. In involving the religion, the Marriage Law of 1974 has driven the Indonesian state authority upon a path which leads to a direction where most of them do not wan to go. In their attempts to deviate from it, they are bound to become ever more engaged.

\section{Conclusion}

The increasing incidence of inter-religious marriage raised the concern of the Indonesian Council of Ulama. Responding to this problem, in June 1, 1980 the Council issued a fatwa which explicitly prohibits a Muslim to marry a non-Muslim. The fatwa does not differentiate between women of the ahl alkitâb and those of other religions. This prohibition finds no literal bases in the basic sources of Islam. The Qur'anic text states that it is lawful to marry women from among the People of the Book, while in the prophetic tradition it is reported that the Prophet himself had a non-Muslim wife. The four leading

the Republic on Indonesia, of the year 1974, with respect to marriage, no longer constitutes an obstacle to the performance of the marriage as desired by them, and in this case/situation the Civil Registry Office is properly obliged, as the only authority qualified to formalize or help formalize marriage between two candidates who do not profess Islam, to accept the applicants' application. (Italics in original) 
Sunni schools of law also permit this kind of marriage under various conditions.

The argument of the fatwa was a reflection of the prevailing concern among the Muslim leaders about the campaign to propagate Christianization which had been tirelessly carried out by well-organized missionnary organizations. Their efforts were reported to have successfully christianized segments of the Indonesian population especially in the heathen hinterland and among outer island tribes. Given the circumstances, the Muslim leaders and ulama perceived interreligious marriage as a hidden Christianization. The position adopted by the fatwa on this issue was quite a radical departure from the prevalent opinion in classical fiqh texts. Even though the fatwa quotes the verse stating permission for a male Muslim to marry among the ahl al-kitâb which traditionally meant the Jews and the Chris-tians, it forbids any marriage between a Muslim and a non-Muslim. However, this legal opinion is still within

\section{BIBLIOGR APHY}

Biltaji, Muhammad. 2002. Manhaj 'Umar ibn al-Khaththâb fî al-Tashrî'.Cairo: Dâr alSalâm.

al-Ghazali. 1997. Al-Mustasfâ min 'Ilm alUsul Vol. 1. Beirut: Muassasah al-Risâlah.

Katz, June S. and Ronald S. Katz. 1975. "The New Indonesian Marriage Law: A Mirror of Indonesia's Politics, Cultural, and Legal Systems," The American Journal of Comparative Law, Vol. 23 No. 4 (Autumn).

. 1978. 'Legislating Social Change in a Developing Country: The New Indonesian Marriage Law Revisited," The American Journal of Comparative Law, Vol. 26 No. 2 (Spring).

Mudzhar, Mohammad Atho. 1993 FatwaFatwa Majelis Ulama Indonesia Studi tentang Pemikiran Hukum Islam di Indonesia, 1975-1988. Jakarta: INIS. the permissible frame of Islamic legal theory of maslahah. This legal theory is encapsulated in the Shafi'i school's legal maxim stating that "Dar'u al-mafâsid muqaddam 'alâ jalb al-masâlih" (Preference is given to the prevention of harm than to attainment of benefit).

The fatwa and the court decisions seem to have little impact on the practices of parties who wish to marry inter-religiously when many state institutions were refusing to conclude their marriage. Many Indonesian, not wishing to lose their religious status, misrepresent their religions to marriage officials. Others have converted to their partner's religion for the purpose of marriage, and then reverted to their original religion a short time later. The negative social and religious implications of the fatwa and court rulings may be pushing people into informal and illegal cohabitation which is on the rise in Indonesia, in particular among couples of mixed religious backgrounds.

Noer, Deliar.1973. The Modernist Muslim Movement 1900-1942. Singapore: Oxford University Press.

Pompe, Sebastian. 1991. "A Short Note of Some Recent Development with Regard to Mixed Marriages in Indonesia," Bijdragen tot de Taal-, Land- en Volkenkunde, Vol 2e \& 3e. Leiden: KITLV Press.

1988. "Mixed Marriage in Indonesia: Some Comments on the Law and the Literature," Bijdragen tot de Taal-, Land-en Volkenkunde, Vol 144. Leiden: KITLV Press.

al-Qaradawi, Yusuf. The Lawful and the Prohibited in Islam, translated by Ahmad Zaki Hammad. n.d. Indianapolis: American Trust Publications.

Shalthûth, Mahmûd. n.d. al-Fatâwâ. Cairo: Dâr al-Qalam.

Suminto, H. Aqib. 1985. Politik Islam Hindia Belanda. Jakarta: LP3ES. 
al-Tûfî, Najm al-Dîn. 1993. Risâlah fi Ri 'âyat al-Maslahah. Cairo: Al-Dar al-Misriyah al-Lubnaniyah.
Udovitch, Abraham. 1970. Partnership and Profit in Medieval Islam. Princeton: Princeton University Press.

al-Zuhaylî, Wahbah.1989. Al-Fiqh al-Islâm wa Adillatuh. Beirut: Dâr al-Fikr. 